\title{
Javanese Cross-gender: The Three Domains of Cabaret Show in Yogyakarta City
}

\author{
Langen Bronto Sutrisno ${ }^{1}$, Sahid Teguh Widodo ${ }^{2}$, Bani Sudardi ${ }^{3}$, Warto ${ }^{4}$

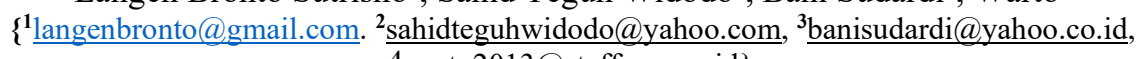 \\ ${ }^{4}$ warto2013@staff.uns.ac.id \\ ${ }^{1234}$ Universitas Sebelas Maret, Indonesia.
}

\begin{abstract}
Cabaret Show in Yogyakarta is a modern genre of Indonesian art performance. Due to the growing negative view on Javanese cross-gender, it deserves a thorough research. This in-depth study aims at identifying the expression, style, genre, and cultural negotiation of cabaret show among the similar modern arts. The data was collected from the informants that include the cabaret show designer, artists, art workers, art observers, audience, cabaret show performance, and other related documents. Based on the data sources, data of this study include verbal information from the informants, textual information from the documents, and visual information from cabaret show performance. This focused single-case study employs cultural perspective and approach by developing the ideology theory introduced by (Althusser, 2014). The validity of the data in the study was measured by peer debriefing while the data was analyzed by interactive analysis model developed by (Miles \& Huberman, 2014). This study found the following results. First, there is a correlation of the three main domains of local wisdom style, Indonesian style, and international trend style that constitute the elements of cabaret show performance in Yogyakarta. Second, the cut points of the three domains show the existence of illusionary (imaginary ideology, transposition of imaginary ideology, and distortion of imaginary ideology that constitutes the characteristics of Javanese cross-gender in Yogyakarta. Third, the study found the existence of cultural negotiation as the basic power of survival and existence, identity, and social control that signify the establishment of a new community that flourishes the life in Yogyakarta.
\end{abstract}

Keywords - Cabaret Show, Javanese cross-gender, Yogyakarta, cultural negotiation.

\section{Introduction}

Cross-gender is a phenomenon in daily life of the art performance [14]. In a simple sense, cross-gender is a form of character breach in which the male character is transformed into the female character or vice versa. Phenomenon of cross-gender in cabaret show performance in Yogyakarta has radically changed the old perception of the people in Yogyakarta as the center for Javanese customs and traditions. 
Accordingly, cross-gender is considered not an ideal identity. Even worse, some people perceive it as misconduct. However, currently, there is a new life style performed in the art of cabaret show. This phenomenon represents the reality that there is a sub culture of 'resistance' in the domination of established and ideal Javanese culture.

The rapid development of cross-gender in Yogyakarta has attracted the attention of some public elements, such as the custom figures, the municipal government, religious bodies, social institutes, and security bodies in Yogyakarta. Such religious groups as FPI (Front Pembela Islam) or Islamic Fighting Front and such security agencies as the district police (polres) and the sub-district military force (koramil) have recognized the presence of the cross-gender community in the cabaret show. Therefore, cabaret show can be adopted as the control as well as the forum for artistic expression of the cross-gender. In addition, it can improve their dignity in the new community. In the process of cabaret show development, some public elements requested explanation before they can accept the presence of cabaret show.

"FPI and the Malioboro security task force came to me. The people of FPI did not threaten at all. They did not come in group. They only came in two. Initially, they forbade me to perform cabaret show. I asked them "why you forbid me. You had better forbid the operation of the prostitute and beauty-plus saloon!" Meanwhile, the staff of Malioboro security came to me. They accused me of a chairman of the LBGT (Lesbian, Bisexual, Gay, and Transgender) group. I told them "I just manage the dances. I do not know about LBGT group. I asked them if they ever saw me having a meeting with LBGT group." In the end, they never came to my home any longer. They could accept cabaret show well" [12].

Cross-gender in cabaret show performance has gradually been accepted by the local people as it is proven that in the performance on Fridays and Saturdays have been attended by approximately 300 visitors.

The role of female character played by a male in cabaret show performance aims to amuse the audience. Widaryanto revealed that the common problem in the performance is that it can be biased and turns into an exclusive "mutual gender abuse". In other words, the performance is merely designed to result in laughter. Therefore, it is not surprising that the existence of cross-gender has been downgraded when compared to other art performance played by the original sexual identity. The lack of state protection and the absence of legal rules have undermined the survival of Indonesian cross-gender artists. Even worse, the Komisi Penyiaran Indonesia (KPI) or Indonesian Broadcast Agency, an independent state agency, has banned the broadcast of the performance that include ladyboy by issuing a circular dated 23 February 2016 No. Surat /K/KPI/02/16 to all broadcasting TV stations TV[6]. Principally, the circular prohibited all broadcast agency to broadcast men in womanish style. The step has indicated the discrimination to all individuals with different gender identities that have become their inherent expression, identity, and ideology.

The cross-gender cabaret show is performed in a restaurant, precisely on the third floor of the Resto Raminten 3 in the Hamzah Batik Building, Gondomanan, Yogyakarta. The performance has played a central role. Even now, it exists in the performance stage. This art is initiated by a cross-gender artist Kanjeng Mas Tumenggung Tanoyo Hamijinindyo (Hamzah Sulaiman), a royal custodian of the Kraton Yogyakarta in 2010. When observed from the form of performance, the ideology of cabaret show consists of three domains. They are local wisdom values, Indonesian style, and international trend. Defined domain limitedly as a category of culture identified by the members of a particular society[11]. In this case Javanese cross-gender is limited in cross-gender in cabaret show with the actual player of males and some trans genders. The Javanese dances represent the local wisdom domain 
while the dangdut koplo repesents the Indonesian style domain and the foreign label represents the international trend domain. Therefore, the ideology in the cabaret show in Yogyakarta that represents the ideology of Javanese cross-gender needs further study.

The three domains are closely correlated with the historical background of the art performance designer and artists. Hamzah Sulaiman has a long and extensive experience as a dancer of classic Javanese dance in the 1960s. Since he was only a child, he has danced the Surakarta-style of fine male character (alusan). With his soft character, Hamzah totally internalizes the role of alusan character. Along his career in art performance, Hamzah has also got involved in the alusan dance of Yogyakarta style. However, his soft character has kept him from performing the war role. In the 1990s, Hamzah was requested by Jogja TV, a local privately-owned TV station in Yogyakarta, to play the role of Raminten, who was a Javanese woman with a funny character. After a long time getting involved in the role of cross-gender in the local TV station, finally Hamzah resigned and started up to organize cabaret show. In 2010, with his hobbies of singing and his habit of walking like women as well as his extensive exposure to cabaret in Thailand, Hamzah was sure to organize a cabaret show.

In addition to Hamzah Sulaiman, cabaret show has also involved an experienced Javanese classic dancer, Joko Gilar. Joko Gilar always plays the role of presenting the local wisdom domains at the beginning of cabaret show. He usually dances the Surakarta-style Gambyong Pareanom, Sekar Pudyastuti, and Yogyakarta-style Panembromo. Although they are danced only at the beginning of cabaret show performance, the Javanese dances are important parts that have to be presented in every performance. The movement, music, and dress have to comply with the prevailing customs and traditions. The Javanese dances in cabaret show performance can be represented by either Yogyakarta-style or Surakarta-style classic dances. The performance of Javanese dances as the opening part of the performance has to be based on the elements of the concepts of classic Yogyakarta-style and Surakarta-style Javanese dances.

One of the artists of Javanese cross-genders that play the role in the Indonesian style domain is Mamok Rahmadona. The movement and music with the genre of dangdut koplo represents the characteristics of currently developing Indonesian culture. Dangdut is an Indonesian-specific music genre that uses the ketipung (a small drum in gamelan ensemble) and seruling (a kind of flute) combined with the rumbling melody in each song lyric. Not only is dangdut a specific genre, it also presents the body swinging that follows the rhythm. Historically, dangdut represents the musical preference of the low-to-middle class of society. Raditya reveals that initially dangdut is classified into the ethnic dangdut, pure dangdut, and typical dangdut. The recently developed dangdut koplo is the new genre of dangdut that grows dand develops from the prohibition. Koplo is associated with the dangdut singer Inul Daratista, who was considered the pioneer. The popularly known Inul's relatively sensual and wild 'goyang ngebor' (the swinging of the body that resembles the drilling movement) has resulted in some controversies. Public interpretation to dangdut koplo varies. Some of them call it a new genre of dangdut, and some others call it 'resistance' dangdut. Still some others call it mixed dangdut [8]. The goyang ngebor is defined as the swinging of the hip downward until the position of half-squat, and with the same swinging movement, return to the original position. The erotic name of goyang ngebor derives from the fact that the buttocks and the genital swing along. Cabaret show in Yogyakarta includes dangdut koplo as a part of the performance. Koplo aims to make the audience laugh during the performance of cross-gender artists. Koplo is intended to attract the audience of commercial performance.

Beside local wisdom domain and Indonesian style domain, there is a international trend 
domain. One of the artists who presents international trend is Sarita Kamasutra. One of the characteristics of international trend presented in cabaret show is the presence of world-class performance, such as imitating the movement, style, appearance, and music from the overseas. Beside that, cabaret show has become one of the tourism icons in Yogyakarta. The "Kedaulatan Rakyat" Daily published on 21 August 2018 released that in addition to be the tourism icon of Yogyakarta, cabaret show has also presented the best talents who can successfully imitate the world-class singers such as Celine Dion, Beyonce, Ariana Grande, Anggun, Agnes Monika, Nicki Minaj and many others[9].

Characteristically, cabaret show in Yogyakarta emphasizes the local wisdom values, Indonesian style, and international trend. The Performance can flexibly follow the prevailing existing cultural rules. Cultural negotiations have formed different ideas of the cabaret genre. Although it is an art of cabaret genre, cabaret show performance keep the cultural characteristics of the people who form the art. It is interesting to study this art as the global performance of cabaret show consistently presents the characteristics of local identity. Therefore, cultural negotiation in cabaret show performance has to be studied.

Beside as a form of performance, another interesting aspect that deserves a study is the effect of the novelty of cabaret show. As a relatively new genre, cabaret show has effects on the social life of the artists. Therefore, a policy to protect the life of cross-gender is needed in order that they can survive and exist in line with the characteristics of the art identity, as well as a social control for the artists who have so far been viewed negatively. The desire to reserve the existence can be observed from the ideas suggested by Hamzah Sulaiman who established the cabaret show as a commercial art performance whose income from ticket sales are proportionally distributed to the artists. The maintenance of existence of the crossgender artists has put the cross-gender artists in a new community in order that they can improve their identity and dignity.

\section{Research Method}

The main location of the study is the stage of cabaret show in the resto Raminten 3, Jl. Margomulyo No. 9 Malioboro, third floor of Hamzah Batik Building. This is a qualitative study since it is considered able to answer the main questions of the study. The study employed the focused single-case study since the issue is unique, different, and even abnormal. However, because the study is focused on a particular case [10] an exploratory approach is possibly used.

Data was collected from the informants who really understand the matters to be studied. They were Hamzah Sulaiman, 69 years, the founder and leader of cabaret show Yogyakarta, Joko Gilar, 47 years, Javanese classic dancer, Mamok Rohmadona, 35 years, multi-talent artists (Indonesian style and International style), and Sarita Kamasutra, 35 years, international trend artist (a trans gender). Other data was collected from documents, photos, and videos of cabaret show performance in Yogyakarta. Data was analyzed interactively [7]. The technique and strategy of the study can understand and explain the representation of image, idea, and ideology of Javanese cross-gender in Yogyakarta. 


\section{Results And Discussion}

\subsection{Three Domains in Cabaret Show in Yogyakarta}

The cabaret show Yogyakarta with its local wisdom values, Indonesian style, and International trend, represents the ideology of the designer and the artists. The three elements have correlation to each other. Local wisdom values among others are manifested in the performance of Javanese dances. The Indonesian style domain is represented in the imitation of movement or swing, characterization, and music of dangdut koplo that represent the characteristics of currently growing popularity of Indonesian style. Meanwhile, international trend is manifested in the foreign symbols. The discourse of the three domains has become the basis for the construction of cabaret show performance in Yogyakarta.

Table 1 describes the three domains identified by the stage name, style and character imitation, song or music, and domain. Stage name is the name used in each performance of cabaret show. Style imitation or character imitation refer to the imitation of style or character of a popular artist. Song and music are the song and music in cabaret show performance. Meanwhile, the domain refers to the part or classification of the art categories.

Table 1: Artists of Cross-gender in Three Domains of the Performance of Cabaret Show 27 April 2018.

\begin{tabular}{|c|c|c|c|c|}
\hline No. & Stage Name & $\begin{array}{l}\text { Style/Character } \\
\text { Imitation }\end{array}$ & Song/Music & Domain \\
\hline 1. & Acipta Sasmi & Anggun C. Sasmi & Tua-tua Keladi & $\begin{array}{l}\text { International Trend, } \\
\text { Indonesian Style }\end{array}$ \\
\hline 2. & Ayla Saras & Aqnes Mo & Teruskanlah & $\begin{array}{l}\text { International Trend, } \\
\text { Indonesian Style }\end{array}$ \\
\hline 3. & Ayu Whulandary & Maurice Chevalier & Ma Pomme & International Trend \\
\hline 4. & Chica Cihuahua & Wiwik sagita & Doremi & Indonesian Style \\
\hline 5. & Debora Fox & Whitney Houston & I Believe I Can Fly & International Trend \\
\hline 6 & Dolce Maria & Nicky Minaj & Bang-bang & International Trend \\
\hline 7. & Jaclyn Vee & Camila Cabello & Havana & International Trend \\
\hline 8. & Jiah Sunrice & Ariana Grande & Bang-bang & International Trend \\
\hline 9. & Luna Kamarie & Dolly Parton & $\begin{array}{l}\text { I Will Always Love } \\
\text { You }\end{array}$ & International Trend \\
\hline 10. & Mamok Bohay & Kridayanti & Penasaran & Indonesian Style \\
\hline 11. & Nindi Bang Bang & Ailee & I Will Show You & International Trend \\
\hline 12. & Rebecca Carter & Rebecca Carter & $\begin{array}{l}\text { Dangerously in } \\
\text { Love }\end{array}$ & International Trend \\
\hline 13. & Sarita Kamasutra & Lady Gaga & The Edge of Glory & International Trend \\
\hline 14. & Suzzaravina & Celuine Dion & That the Way it is & International Trend \\
\hline 15. & Joko Gilar & $\begin{array}{l}\text { Penari Gambyong } \\
\text { Pareanom }\end{array}$ & Javanese Music & $\begin{array}{l}\text { Local wisdom } \\
\text { values }\end{array}$ \\
\hline
\end{tabular}

Beside its attractive performance, cabaret show in Yogyakarta is enriched by the presence of the cross-gender artists with the three domains. The cross-gender actors present the three domains. The local wisdom values include Javanese cross-gender. The cross-gender artist that imitates the swing and character of dangdut koplo, while the international trend is played by cross-gender artist who can imitate foreign artists represents the Indonesian style. Althusser suggested that ideology 'serves' at the most concrete level or at the individual 'subject $\backslash$ level. It operates at the context of how people live their individuality, job, daily life, action, 
commitment, hesitation, and feeling about what will automatically be proven[1]. Ideology of the actors forms the concrete individuals to become cross-gender actors different from their real gender that has been previously socially constructed in the society. Currently, the concrete individuals turn into the culturally reconstructed subject. According to Althusser, subject is an effect or result of ideology. The discourse in the ideology constructs the subject. The role of Javanese cross-gender in cabaret show is actually constructed from the discourse of ideology. Based on the character that the artist plays, some actors play Javanese cross-gender in their daily life. They are strongly active and committed. However, some actors feel hesitate in playing as the Javanese cross-gender actors. An artist who is very committed with his role is Joko Gilar. He is an artist of Javanese cross-gender that promotes Javanese local wisdom values. Even, Sarita Kamasutra, an artist with a trans-gender identity explicitly and openly admits that she is a committed artists of Javanese cross-gender. She is sure with what she has preferred in the show and in the daily life. However, some other actors hesitate when they play the role of Javanese cross-gender. They hide their identity of cross-gender actors from the public. Cabaret show is flexible in applying the three domains in order that the three domains are related to each other. For example, in the aspect of the form of performance, the classic Javanese dance can be reconstructed to become a new genre of international cabaret. Likewise are the actors. For example, Gambyong Pareanom dance that is commonly danced by women, it can be danced by men in cabaret show, which is identically characterized by cross-gender artists. The correlation among the three domains of cabaret show is elastic in forming the performance art in a new genre.

\subsection{Characteristics of Javanese Cross-gender in Cabaret Show in Yogyakarta}

In applying the three domains, cabaret show performance is flexible. There are cultural negotiations in the form and actors. The following scheme illustrates the flow chart of the domains in cabaret show.

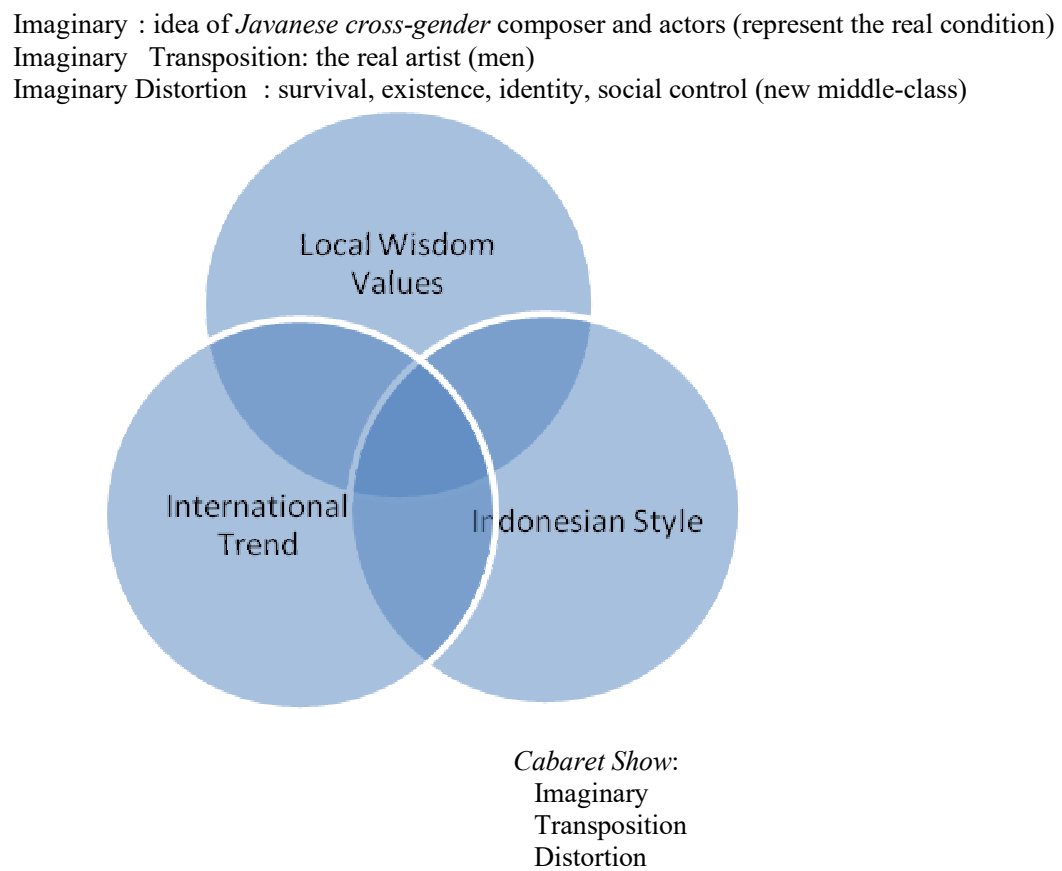


Negotiation among the constituting factors of the art of cabaret show is apparent in the elements of accompaniment, dress, and expression. The cutting point of the negotiation of cabaret show performance finds the power called by Althuser imaginary, imaginary transposition, and imaginary distortion. The composer's and actors' idea of Javanese crossgender is known as the illusion or imaginary ideology. Imaginary ideology of the composer and actors represent the real condition through cabaret show performance. Therefore, it has to be connected to the reality to interpret the representation of imaginary Javanese cross-gender. However, what appears as women is actually the opposite. They are actually men. Thus, an Ideology is by Althusser called imaginary transposition. Beside that, imaginary ideology represents the condition of existence, survival consideration, identity, and social control of the actors of Javanese cross-gender, which is called imaginary distortion in ideology.

The cut points of the three domains in cabaret show indicate the power of ideology in the forms of imaginary, imaginary transposition, and imaginary distortion. The three domains serve as the characteristics of the performance. The strength of the images has turned into the specific characteristics of the art, which further tuned into a new genre of art in Indonesia. This power brings tremendous effects on the performance, actors, and society. The power of imaginary has made the art survive although it is attacked by the negative perception that the art represents resistance culture.

\subsection{Effect of Performance of Cabaret Show}

The effect of performance art of cabaret as a new genre includes the matters of imaginary distortion. The effects are survival, existence, identity, and social control that constitute the new community. The colorful imaginary distortion is observable in cabaret show with the appearance of cross-gender as an art with specific and unique attraction for commercialism. The income earned by the actors is ideal as an odd job beyond the primary job of the actors. The improvement of welfare for cross-gender Javanese classic dancers, cross-gender artists with swing of dangdut koplo, and artists with international trend is very apparent. Featherstone said that currently the artists earn quite adequate amount of money and some them get a much better life by getting involved in the art[3]. As one of artists of admits it cross-gender that have concerned in the Javanese local wisdom values, Joko Gilar "the cabaret show was initially intended to be the media of expression and hobby. After we performed on stage several times, and we get some honor, o..... c can live with it" [4]. On the other hand, the leader of cabaret show is the capital investor. He may be one of the philanthropic producers. Hamzah is very loyal to the art. His concern and care for the individuals with the same interests as him is quite high. That is why he involves cross-gender artists in dignity. The manager of art Bunda Ayu explained that Hamzah plays the role of designer, pioneer, and capital supporter for the cabaret show.

"The boss does not take any benefit at all. He shares all of the income from the ticket sales for the creativity and prosperity of the actors, technicians, and crews. The boss only facilitates, arranges the place, and provides the capital. Now we manage the capital". [2].

Cabaret show is a form of aesthetics for cross-gender artists. Cabaret show can provide a new genre of art for the audiences and lovers. The novelty indicates that the new identity and ideology has become a new trend in the urban night entertainment.

Performance of cabaret show in Yogyakarta has improved the value of an art and the actors as well. The Identity of cross-gender artists in cabaret show performance is generally male and some them have trans gender. One of the trans gender actors is Sarita Kamasutra. He admitted that "my sex orientation is female. I express my sexaual orientation through the dress and makeup" [5]. Meanwhile, an artist of cross-gender who is actually male, Ahmad 
Susan Tri, said that "those who are actually men prefer to be called ladyboys to the judging stereotype of banci, bencong, or waria" [13] [14].

Cabaret show performance in Yogyakarta indirectly is a social control for the actors. The cabaret show has improved the actors' concern on the roles that they can perform with creative ideas to attract the audience. They are responsible for a good and attractive performance in order that they can earn some honorarium that can support their life and avoid them from negative activities [15].

\section{Conclusion}

The existence of cabaret show in Yogyakarta is the form of expression of the ideology of the composer and the artists in the public space. Three domains constitute the forms of the appearance of cabaret show. They are the domains of local wisdom values, Indonesian Style, and International Trend. The three domains are elastically correlated. The three domains have clear distinction. However, after the cultual negotiation, the three domains can flexibly interrelated in cabaret show performance.

Table 3: Cultural Negotiation of cabaret show in Yogyakarta City

\begin{tabular}{|c|c|c|c|c|}
\hline No & Domains & Sources & $\begin{array}{l}\text { Distinguished } \\
\text { Characteristics }\end{array}$ & Cultural negotiation \\
\hline 1 & $\begin{array}{l}\text { Local wisdom } \\
\text { values }\end{array}$ & $\begin{array}{l}\text { Javanese } \\
\text { Tradition }\end{array}$ & $\begin{array}{l}\text { Style } \\
\text { Appearance }\end{array}$ & $\begin{array}{l}\text { - Costume } \\
\text { - Character }\end{array}$ \\
\hline 2 & Indonesian Style & $\begin{array}{l}\text { Indonesian } \\
\text { Nationality }\end{array}$ & $\begin{array}{l}\text { Appearance } \\
\text { Movement } \\
\text { Character } \\
\text { Lip sync }\end{array}$ & $\begin{array}{l}\text { - Character } \\
\text { - Expression } \\
\text { - Movement } \\
\text { - Accompaniment }\end{array}$ \\
\hline 3 & $\begin{array}{l}\text { International } \\
\text { Trend }\end{array}$ & International & $\begin{array}{l}\text { Appearance } \\
\text { Movement } \\
\text { Character } \\
\text { Lip sync }\end{array}$ & $\begin{array}{l}\text { - Character } \\
\text { - Expression } \\
\text { - Movement }\end{array}$ \\
\hline
\end{tabular}

The cutpoints of the thee domains of cabaret show have built the power. They are imaginary ideology, imaginary ideology transposition, and imaginary ideology distortion. Imaginary ideology is the idea of the composer and the artists. Meanwhile, imaginary ideology transposition indicates the contrary condition. Although they are actually men, they dress up as women. Finally, imaginary ideology distortion is the effects that colors the presence of cabaret show such as survival, existence, identity, and social control as a form of the establishment of a new community.

The cabaret show as a new genre of art has undergone a process of cultural negotiation in the three domains. The effects of the cultural negotiation are survival, existence, identity and social control that constitute the establishment of a new community. The survival is indicated by the sustainable performance of cross-gender in line with the ideology to earn additional income to support their life. The existence is indicated by the routine performance on stage and publication in some mass media such as the printed media in Yogyakarta and the publication in the internet. The identity is obtained through the novelty of the performance art of cabaret that represents a new unique and specific genre. Unintentionally, cabaret show 
performance serves as a social control to enable expression and creativity and to reduce negative perspectives.

\section{References}

[1] Widaryanto, F. Menuju Representasi Dunia Dalam. Bandung: Kelir, 2007.

[2] Sulaiman, Hamzah (Hamijinindyo, K. M. T. No Title. Yogyakarta, 2019.

[3] Komisi Penyiaran Indonesia Lembaga Negara Independen. "Edaran Kepada Seluruh Lembaga Penyiaran Mengenai Pria yang Kewanitaan. ”, (2016).

[4] Spradley, J. Metode Etnografi. Yogyakarta: Tiara Wacana, 2006.

[5] Raditya, M. H. B. "Dangdut Koplo: Memahami Perkembangan Hingga Pelarangan.” Jurnal Seni Dan Budaya Nusantara Studi Budaya Nusantara. Retrieved from https://jsbn.ub.ac.id/index.php/sbn/article/view/2/2, 2017.

[6] Raminten Cabaret Show Hadirkan Diva Dunia. August Kedaulatan Rakyat, p. 9, 2018

[7] Ratna, N. K. Metodologi Penelitian Kajian Budaya dan Ilmu Sosial Humaniora pada Umumnya. Yogyakarta: Pustaka Pelajar, 2016.

[8] Miles, M. B., \& Huberman, A. M. Analisis Data Kualitatif: Buku Sumber Tentang MetodeMetode Baru. Jakarta: UI-Press, 2014.

[9] Featherstone, M. Posmodernisme dan Budaya Konsumen. Yogyakarta: Pustaka Pelajar, 2008.

[10] Gilar, J. No Title. Yogyakarta, 2019.

[11] Ayu, Bunda (Budiono, R. No Title. Yogyakarta, 2019.

[12] Kamasutra, S. No Title. Yogyakarta, 2019.

[13] Susan Tri, A. No Title. Yogyakarta, 2018.

[14] Althusser, L. On The Reproduction of Capitalism: Ideology and Ideological State Aparatuses. London: Verso, 2014.

[15] K. Saddhono, "Cultural and social change of foreign students in Indonesia: The influence of Javanese Culture in Teaching Indonesian to Speakers of Other Languages (TISOL)." IOP Conf. Ser.: Ear. and Envi. Sci.. vol. 126 no. 1. IOP Publishing, 2018. 